\title{
Consumption of ultra-processed foods and body fat during childhood and adolescence: a systematic review
}

\author{
Caroline Santos Costa*, Bianca Del-Ponte, Maria Cecília Formoso Assunção and \\ Iná Silva Santos \\ Postgraduate Program in Epidemiology, Federal University of Pelotas, Rua Marechal Deodoro $1160-3^{\circ}$ andar, \\ Pelotas, RS, CEP 96020-220, Brazil
}

Submitted 15 October 2016: Final revision received 8 May 2017: Accepted 18 May 2017: First published online 5 July 2017

\begin{abstract}
Objective: To review the available literature on the association between consumption of ultra-processed foods and body fat during childhood and adolescence.

Design: A systematic review was conducted in the PubMed, Web of Science and LILACS databases. Studies that evaluated the association between consumption of ultra-processed food (exposure) and body fat (outcome) during childhood and adolescence were eligible.

Subjects: Healthy children and adolescents.

Results: Twenty-six studies that evaluated groups of ultra-processed foods (such as snacks, fast foods, junk foods and convenience foods) or specific ultra-processed foods (soft drinks/sweetened beverages, sweets, chocolate and ready-to-eat cereals) were selected. Most of the studies ( $n$ 15) had a cohort design. Consumption was generally evaluated by means of FFQ or food records; and body composition, by means of double indirect methods (bioelectrical impedance analysis and skinfolds). Most of the studies that evaluated consumption of groups of ultra-processed foods and soft drinks/sweetened beverages found positive associations with body fat.

Conclusions: Our review showed that most studies have found positive associations between consumption of ultra-processed food and body fat during childhood and adolescence. There is a need to use a standardized classification that considers the level of food processing to promote comparability between studies.
\end{abstract}

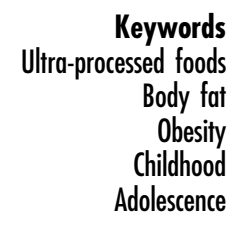

Childhood and adolescent obesity has presented a growing prevalence over the last three decades ${ }^{(1)}$. Over the same period, modifications to how foods are produced and increasing availability of transportation facilities have been observed, characterizing an 'obesogenic' environment ${ }^{(2)}$ with increasing prevalence of non-healthy eating habits ${ }^{(3)}$ and decreasing prevalence of physical activity ${ }^{(4)}$. The dietary profile of populations within this scenario has become characterized by high energy density, in which foods rich in fibre have been replaced by products rich in fat and sugars, with a high level of processing ${ }^{(3,5)}$.

A recent food classification (NOVA) based on the extent and purpose of industrial food processing has divided foods into four groups: unprocessed or minimally processed foods; processed culinary ingredients; processed foods; and ultra-processed foods. This last category comprises a group of industrial formulations that are manufactured using several ingredients and a series of processes $^{(6-9)}$. Most of these products contain little or no whole food. They are ready-to-consume or ready-to-heat and thus require little or no culinary preparation, which makes them easily accessible and convenient. Typically, they are combined with sophisticated use of additives, to make them durable and hyper-palatable. However, they have very low nutritional quality and their consumption tends to limit consumption of unprocessed or minimally processed foods ${ }^{(6-9)}$.

Consumption of ultra-processed foods has been pointed out as a risk factor for increasing obesity, as measured by BMI, among both adolescents and adults ${ }^{(10,11)}$. Moreover, it has been shown in the literature that individuals who are obese at an early age tend to remain obese throughout 
life ${ }^{(12)}$. Considering the growing prevalence of obesity and the consumption of ultra-processed foods worldwide, the objective of the present systematic review was to identify papers on the association between consumption of ultra-processed food and body fat during childhood and adolescence.

\section{Methods}

\section{Search strategy}

The search was performed in two worldwide electronic databases (PubMed and Web of Science) and in a Latin American and Caribbean database (LILACS). Terms relating to body composition and to consumption of ultra-processed foods were used. The search key was composed of combinations of the following terms: ('body composition' OR 'fat free mass' OR 'fat mass' OR 'dual-energy X-ray absorptiometry' OR 'bioelectrical impedance' OR 'plethysmography' OR 'DEXA scan' OR 'DXA scan' OR 'body fat' OR 'bodpod' OR 'lean mass' OR 'adiposity') AND ('ultra processed' OR 'ultraprocessed' OR 'ultra-processed' OR 'ready-to-eat' OR 'ready-to-consume' OR 'industrialized' OR 'fast-food' OR 'fast food' OR 'fastfood' OR 'junk food' OR 'prepared food' OR 'candy' OR 'ice cream' OR 'chocolate' OR 'carbonated beverage' OR 'soft drink' OR 'sweetened beverage' OR 'snacks' OR 'sausage' OR 'hot dog' OR 'burger' OR 'dietary patterns' OR 'dietary behaviors' OR 'dietary habits'). There were no restrictions to the search regarding topic. All papers needed to be original studies conducted on human subjects. The search was last updated on 15 July 2016.

In addition to the electronic search, the reviewers also undertook a hand search in the reference list of each study included, to identify potentially relevant studies that had not been reached in the initial search.

\section{Eligibility criteria}

To be eligible, the studies had to fulfil the following criteria. They needed to: evaluate the association between consumption of ultra-processed food and body fat; evaluate the exposure (consumption of ultra-processed food) and the outcome (body fat) during childhood or adolescence; and not solely include individuals with specific diseases or health conditions.

The exposure variable was the intake of any ultraprocessed food, as defined in the NOVA classification (see online supplementary material, Supplemental Table 1) ${ }^{(6-9)}$. Studies that evaluated only BMI as the outcome were not included because BMI does not discriminate between fat mass and fat-free mass.

\section{Selection of the studies}

Two independent reviewers conducted an initial selection of the articles located in the electronic search, by means of reading the titles and abstracts. The papers selected at this stage were then read in full and were evaluated in accordance with the eligibility criteria. A third reviewer adjudicated regarding whether articles should be kept or excluded in situations in which the two reviewers disagreed.

\section{Data analysis}

From the full analysis on the articles thus selected, the following data were extracted: country and publication year; study design; sample size; age group evaluated; methods and instruments used to measure the exposure and outcome variables; variables used to control for confounding and in the mediation analysis (when present); and main findings.

The general and methodological quality of observational studies was evaluated in accordance with the STROBE (Strengthening the Reporting of Observational Studies in Epidemiology) Statement ${ }^{(13)}$. The CONSORT (Consolidated Standards of Reporting Trials) Statement ${ }^{(14)}$ was used to evaluate intervention studies. The maximum scores that can be attained is 22 points in the STROBE assessment and 25 points in CONSORT; of which 9 and 10 points, respectively, related to the Methods section of the studies.

\section{Results}

The electronic search resulted in 2243 titles (Fig. 1). After removing duplicates, 1553 titles/abstracts remained to be analysed. From reading the titles and abstracts, and in accordance with the eligibility criteria, Reviewer 1 and Reviewer 2 excluded 1498 and 1519 articles, respectively. After full readings of the articles, Reviewer 1 excluded another twenty-eight articles and Reviewer 2, nineteen, of which nine were coincident. The reasons for exclusion of the articles were that they presented:

- Investigation of ultra-processed food consumption and body fat, but not the association between these two variables ( $n$ 17);

- Investigation of food consumption by means of scores or dietary indices, from which it was not possible to discriminate the consumption of ultra-processed foods ( $n$ 5);

- Evaluation of food consumption according to dietary patterns or by means of specific questionnaires such as the 'Block' questionnaire, which asks not only about ultra-processed foods, but also about other food groups, such as unprocessed or minimally processed foods $(n$ 4);

- Food consumption based on their components (macronutrients, sugar and energy density; $n$ 4);

- No evaluation of the outcome or the exposure of interest ( $n$ 2);

- Use of behavioural clusters, including consumption of fruits and vegetables, consumption of soft drinks, sedentary behaviour and physically active behaviour $(n 1)$;

- Evaluation of the frequency with which adolescents had meals in fast-food restaurants, without evaluation of the foods consumed ( $n$ 1); 


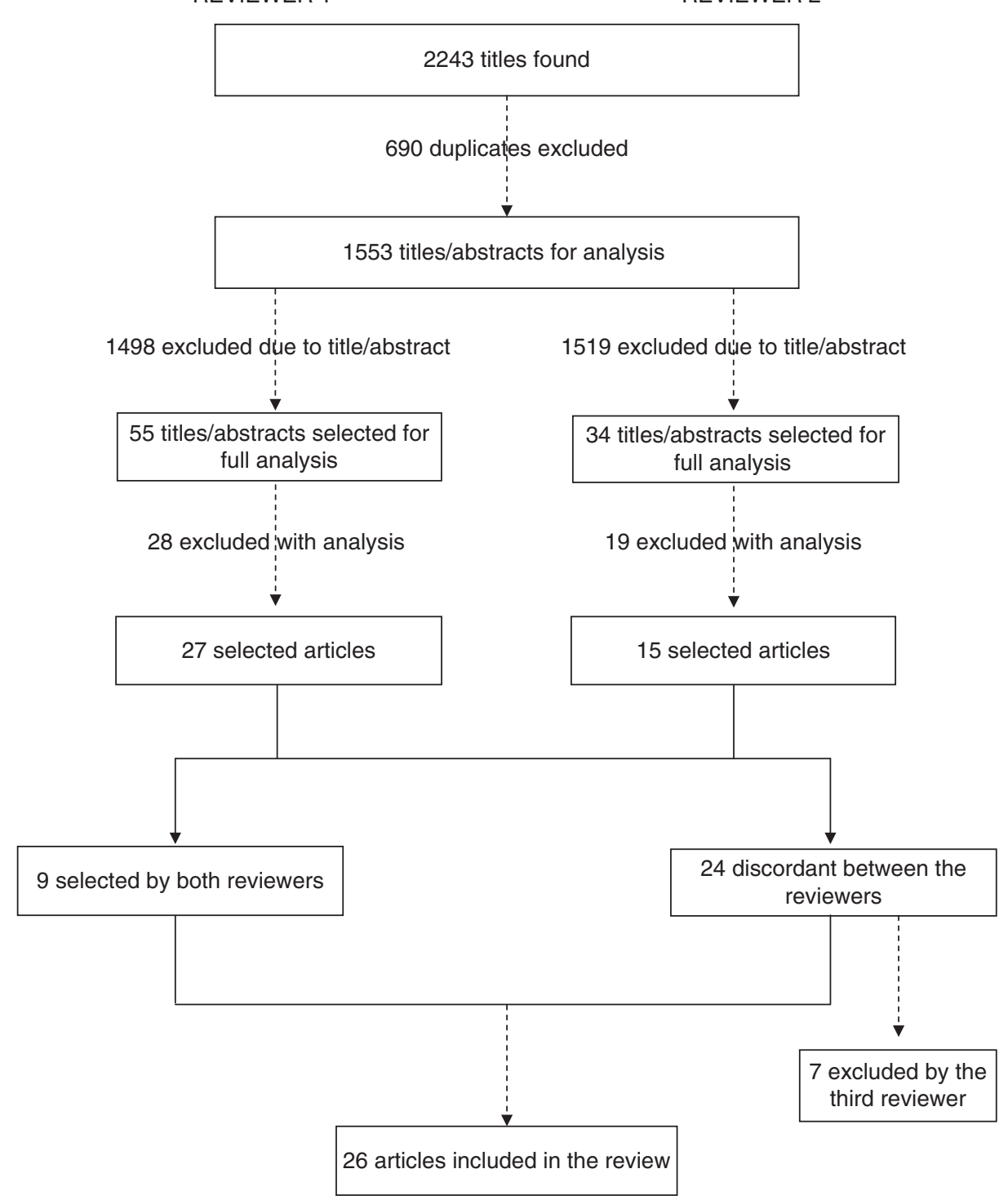

Fig. 1 Flowchart of article selection for the present systematic literature review on consumption of ultra-processed foods and body fat during childhood and adolescence

- Evaluation of Indigenous populations ( $n$ 1);

- Evaluation of fast-food consumption without discriminating which foods belong to this group ( $n 1)$;

- Evaluation of consumption of sugar that is not considered ultra-processed in the NOVA classification ( $n$ 1);

- Evaluation of an intervention composed of changes to physical activity, concomitant to consumption of readyto-eat cereals, which hindered evaluation of the specific effect of ready-to-eat cereals ( $n$ 1).

After full readings of the articles, the two reviewers agreed regarding selection of nine studies and disagreed regarding twenty-four. The third reviewer judged the relevance of the twenty-four articles on which the two previous reviewers had disagreed and decided to exclude seven of them. The reasons for the seven exclusions at this stage were that they presented:

- Investigation of ultra-processed food consumption and body fat, but not the association between these two variables $(n 4)$;

- Evaluation of food consumption according to dietary patterns or by means of specific questionnaires such as the 'Block' questionnaire, which asks not only about ultra-processed foods, but also about other food groups, such as unprocessed or minimally processed foods ( $n$ 2);

- Body fat analysed as the ratio of two skinfolds (subscapular to triceps skinfold), which only evaluates the fat distribution, and not the quantity of fat $(n$ 1) 
No other papers were located through the hand search in the reference lists of the articles selected. A total of twentysix studies were retained for the current review.

Among these twenty-six selected articles, twelve evaluated the association between consumption specifically of soft drinks or sweetened beverages and body fat ${ }^{(15-26)}$, eleven explored the association between groups of ultra-processed foods and body fat ${ }^{(27-37)}$ and three evaluated the association between consumption of specific ultra-processed foods (sweets, chocolate and readyto-eat cereals) and body fat ${ }^{(38-40)}$.

Seven studies were conducted in the USA ${ }^{(19,21,22,27-29,33)}$, four in the $\mathrm{UK}^{(15,24,25,37)}$, three in Germany ${ }^{(18,30,35)}$, two in New Zealand ${ }^{(17,32)}$ and one each in Australia ${ }^{(26)}$, South Africa $^{(31)}$, Canada ${ }^{(36)}$, Netherlands ${ }^{(34)}$, Mexico ${ }^{(16)}$, Spain ${ }^{(20)}$ and Brazil ${ }^{(38)}$. Three were multicentre studies: one was carried out in four Oceania countries (New Zealand, Australia, Fiji and Tonga $)^{(23)}$; and the other two were conducted in ten European cities in nine different countries (Austria, Belgium, France, Germany, Greece, Hungary, Italy, Spain and Sweden) ${ }^{(39,40)}$. The articles selected were published between 2004 and 2015 .

Most of the studies were cohorts ( $n$ $15)^{(15,16,18,19,22,24,25,27-31,35-37)}$, although two of these only presented cross-sectional analyses ${ }^{(16,36)}$; followed by crosssectional studies $(n 6)^{(17,20,32,38-40)}$; and intervention studies $(n 5)^{(21,23,26,33,34)}$, among which three only presented crosssectional analyses ${ }^{(21,23,33)}$ (Table 1 ). In four studies, only girls were evaluated $^{(19,21,27,28)}$. The sample size ranged from 120 to 13170 individuals. Twelve studies had sample sizes larger than 1000 individuals $(16,17,20,23-25,28,31,34,37,39,40)$ (Table 1).

Regarding the age of the samples studied, in the longitudinal studies (cohort and intervention studies) the mean age at which the exposure was evaluated ranged from $7 \cdot 8$ (SD 3.6) to 8.49 (SD 4.0) years, and the mean age at which the outcome was assessed ranged from 13.5 ( $\mathrm{SD} 3 \cdot 3$ ) to $14 \cdot 1$ (SD 3.6) years. In the studies with cross-sectional analysis, the mean age ranged from 11.2 (SD 3.3) to $15 \cdot 8$ (SD 3.0) years.

Food consumption was investigated using four different types of instrument. Eight studies used $\mathrm{FFQ}^{(16,17,27,31,32,37,38,40)}$; seven used food records (referring to three days: two weekdays and one day at the weekend ${ }^{(15,18,24,28-30,35)}$; six applied $24 \mathrm{~h}$ recalls ${ }^{(19,20,22,26,36,39)}$; and five asked questions about the consumption of specific foods ${ }^{(21,23,25,33,34)}$ with varying recall periods (last month, last week, last $5 \mathrm{~d}$ or the day before the interview; Table 1).

Except for the studies that evaluated the consumption of specific ultra-processed foods $\left(\begin{array}{ll}n & 15\end{array}\right)^{(15-26,38-40)}$, the analysis on food consumption in the remaining studies was performed by means of dietary patterns $(n 6)^{(28,29,32,35-37)}$; or according to groups of specific foods ( $n$ 5) such as energy-dense snacks (soft drinks, sweets, crisps, bakery products and ice cream; $n 2)^{(27,34)}$, or through investigation of fast foods, bakery foods and soft drinks $(n 1)^{(31)}$, junk foods (sweetened beverages, French fries and crisps, frozen/baked desserts and chocolate sweets; $n 1)^{(33)}$ or convenience foods (pre-baked frozen products, canned or instantaneous products such as salads

Table 1 Description of the main characteristics observed in the studies selected for the present systematic literature review on consumption of ultra-processed foods and body fat during childhood and adolescence ( $n$ 26)

\begin{tabular}{|c|c|c|c|c|}
\hline Characteristic & $\begin{array}{l}\text { Groups of } \\
\text { ultra-processed foods* } \\
(n 11)\end{array}$ & $\begin{array}{c}\text { Soft drinks/ } \\
\text { sweetened beverages } \\
(n \text { 12) }\end{array}$ & $\begin{array}{c}\text { Other specific } \\
\text { ultra-processed foods } \dagger \\
(n 3)\end{array}$ & $\begin{array}{c}\text { Total } \\
(n \text { 26) }\end{array}$ \\
\hline \multicolumn{5}{|l|}{ Design } \\
\hline Cohort & 8 & 7 & 0 & 15 \\
\hline Cross-sectional & 1 & 2 & 3 & 6 \\
\hline Intervention & 2 & 3 & 0 & 5 \\
\hline \multicolumn{5}{|l|}{ Sample size } \\
\hline$<300$ & 3 & 4 & 1 & 8 \\
\hline $300-1000$ & 4 & 2 & 0 & 6 \\
\hline$>1000$ & 4 & $\overline{6}$ & 2 & 12 \\
\hline \multicolumn{5}{|c|}{ Evaluation of food consumption } \\
\hline FFQ‡ & 4 & 2 & 2 & 8 \\
\hline Food record & 4 & 3 & 0 & 7 \\
\hline $24 \mathrm{~h}$ recall & 1 & 4 & 1 & 6 \\
\hline Specific question & 2 & 3 & 0 & 5 \\
\hline \multicolumn{5}{|c|}{ Evaluation of body composition } \\
\hline DXA & 4 & 5 & 0 & 9 \\
\hline $\mathrm{BIA}$ & 3 & 5 & 2 & 10 \\
\hline Skinfolds & 4 & 2 & 1 & 7 \\
\hline \multicolumn{5}{|l|}{ Associations } \\
\hline Direct & 6 & 8 & 0 & 14 \\
\hline Inverse & 0 & 0 & 2 & 2 \\
\hline No association & 5 & 4 & 1 & 10 \\
\hline
\end{tabular}

DXA, dual-energy X-ray absorptiometry; BIA, bioelectrical impedance analysis.

*Dietary patterns, snacks, fast foods, junk foods and convenience foods.

†Chocolate, sweets and ready-to-consume breakfast cereals.

†Recall period: annual ( $n$ 2), weekly $(n 2)$ and no available information ( $n 4)$. 
or soups, or ready-to-eat meals, like pizzas, except fast foods; $n 1)^{(30)}$.

In the studies that evaluated dietary patterns, the ultraprocessed groups included snacks (like crisps or chocolates), sweets, convenience foods and fast foods ${ }^{(28)}$; snacks and convenience foods ${ }^{(35)}$; fast foods (sweetened beverages, French fries, fried chicken, salted snacks, hamburgers, hotdogs and pizzas) ${ }^{(36)}$; artificially sweetened beverages and manufactured sauces and butters ${ }^{(29)}$; bakery products, carbonated beverages, sweets, crisps, sausages, hamburgers, pizzas, cookies, instant noodles, ready-to-eat meals and aromatized milk $^{(37)}$; and sweets, bakery products, crisps and natural or artificially sweetened beverages ${ }^{(32)}$.

Three methods for evaluating body fat were used. Ten studies obtained body fat measurements by means of bioelectrical impedance analysis (BIA) ${ }^{(17,22,23,25-27,32,33,38,39)}$; followed by nine through dual-energy X-ray absorptiometry (DXA) ${ }^{(15,16,19,21,24,29,31,36,37)}$; and seven from skinfolds $^{(18,20,28,30,34,35,40)}$ (Table 1). Body fat was analysed as a percentage in sixteen articles ${ }^{(16-22,25-28,30,33,36,38,40)}$ and in kilograms in four ${ }^{(24,29,31,37)}$, while another three studies presented body fat both in kilograms and as a fat mass index $(\mathrm{FMI})^{(15,32,35)}$ and two, as both a percentage and in kilograms ${ }^{(23,39)}$. One study used the sum of the triceps, biceps, suprailiac and subscapular skinfolds (in millimetres) as a proxy for the body fat component ${ }^{(34)}$.

Regarding study quality, the mean totals were $17 \cdot 1$ and 18.0 points, respectively, for the observational studies ( $n$ 24) and intervention studies $(n 2)^{(26,34)}$. The mean score reached in the Methods section was 7 points for studies evaluated using both the STROBE Statement and the CONSORT Statement.

Among the studies that evaluated the association between consumption of groups of ultra-processed foods and body fat $(n 11)^{(27-37)}$, six found associations ${ }^{(29-31,35-37)}$, which were all in a positive direction (i.e. higher consumption of ultra-processed foods was related to higher levels of body fat). All the studies that showed this association had a longitudinal design (cohort; Table 2).

Among the studies that evaluated the association between consumption of soft drinks/sweetened beverages and body fat $(n 12)^{(15-26)}$, eight found associations ${ }^{(16,17,19,22-26)}$, which were all in a positive direction (i.e. higher consumption of soft drinks/sweetened beverages was followed by higher levels of body fat; Table 3). Laska et al. ${ }^{(22)}$ found an association with a positive direction only in relation to consumption of sweetened beverages among boys, in a longitudinal analysis, and of diet soda among girls, in a cross-sectional analysis. However, the result for girls may have reflected reverse causality bias, given that those with excess body fat might have reported higher consumption of diet products because of their condition (Table 3). The studies that showed this association mostly had a longitudinal design (cohort or intervention; Table 3).
Among the studies that evaluated the association between consumption of other ultra-processed foods (sweets $^{(38)}$, chocolate $^{(39)}$ and ready-to-eat cereals ${ }^{(40)}$ ) and body fat, two found associations with a negative direction (i.e. increased consumption of chocolate ${ }^{(39)}$ and readyto-eat cereals ${ }^{(40)}$ was associated with a lower percentage of body fat; Table 4).

The main variables used in the adjusted analyses were total energy intake, residual energy intake (energy intake from sources other than the foods evaluated), physical activity, age, sex, skin colour/ethnicity, parents' education and BMI, age at the menarche or at sexual maturation, birth weight and breast-feeding. In the present review, divergent opinions were observed regarding use of total energy intake as a possible confounding factor. Out of the twenty-six studies, nine adjusted for total energy intake $^{(15,16,19,22,26,29,36,37,39)}$ and five adjusted for residual energy intake $(18,24,25,27,30)$. None of the studies investigated whether total energy intake mediated the effect of consumption of ultra-processed foods or soft drinks on body fat. Two articles did not present adjusted analysis $^{(20,38)}$ and the remaining studies adjusted for variables other than energy intake.

\section{Discussion}

In summary, the present review showed that most of the studies that investigated consumption of groups of ultra-processed foods, as well as most of the studies that evaluated consumption of soft drinks/sweetened beverages, found positive associations with body fat. The lack of association in some of the studies may have been due to methodological issues. First, body fat was measured using three different methods (DXA, BIA and skinfolds). Among the studies that found associations, half used $\operatorname{DXA}^{(16,19,24,29,31,36,37)}$, and among those that did not find any association, only two used this equipment ${ }^{(15,21)}$. Although the DXA method evaluates body composition indirectly, it has the capacity to derive measurements of greater validity than is possible using doubly indirect methods such as BIA and skinfolds.

Second, the instruments for the food consumption evaluation also varied among the studies (FFQ, food record, $24 \mathrm{~h}$ recall and specific questions). Although all these instruments generate information about consumption of certain groups of ultra-processed foods or about a specific ultra-processed food, a great variety of products were included, which could at least partly explain the divergence among the findings. For example, dietary patterns vary according to sex, socio-economic level, ethnic group and culture, such that specific dietary patterns are derived for each specific population ${ }^{(41)}$. This impairs the comparability of findings between studies ${ }^{(41)}$. Six of the studies analysed here derived dietary patterns ${ }^{(28,29,32,35-37)}$. 
Table 2 Summary of the selected studies that investigated the association between consumption of groups of ultra-processed foods and body fat in children and adolescents

\begin{tabular}{|c|c|c|c|c|c|c|}
\hline $\begin{array}{l}\text { Authors, year, } \\
\text { reference; country }\end{array}$ & Design & $\begin{array}{l}\text { Study population } \\
\text { ( } n \text {, age, follow-up) }\end{array}$ & Exposure & Outcome & Adjustment variables & Main results \\
\hline $\begin{array}{l}\text { Phillips et al. }(2004)^{(27)} \text {; } \\
\text { USA }\end{array}$ & Longitudinal & $\begin{array}{l}n 132 \text { (only girls; 8-12 } \\
\text { years old; } 4 \text { years } \\
\text { of follow-up) }\end{array}$ & $\begin{array}{l}\text { FFQ; snack groups of } \\
\text { high energy density: } \\
\text { soft drinks, sweets, } \\
\text { crisps, bakery } \\
\text { products and ice } \\
\text { cream }\end{array}$ & BF\% evaluated by BIA & $\begin{array}{l}\text { Physical activity index, } \\
\text { inactivity time, parental } \\
\text { overweight, race/ethnicity, } \\
\text { daily servings of fruits and } \\
\text { vegetables, percentage of } \\
\text { daily energy from protein, } \\
\text { carbohydrates and fat. Age } \\
\text { was expressed as } \\
\text { chronological age and age } \\
\text { at menarche was included } \\
\text { as a fixed covariate }\end{array}$ & $\begin{array}{l}\text { No association between daily } \\
\text { portions of snacks and BF\% } \\
(\log =0.20 ; P=0.49)\end{array}$ \\
\hline $\begin{array}{l}\text { Ritchie et al. }(2007)^{(28)} \\
\text { USA }\end{array}$ & Longitudinal & $\begin{array}{l}n 2371 \text { (only girls; } 9-10 \\
\text { years old; } 10 \text { years } \\
\text { of follow-up) }\end{array}$ & $\begin{array}{l}\text { Food record; dietary } \\
\text { patterns }\end{array}$ & $\begin{array}{l}\text { BF\% evaluated by } \\
\text { skinfolds (triceps, } \\
\text { subscapular and } \\
\text { suprailiac) }\end{array}$ & $\begin{array}{l}\text { Corresponding baseline } \\
\text { measure of adiposity, age at } \\
\text { menarche, ever pregnant } \\
\text { over the course of the } \\
10 \text {-year study, maximal } \\
\text { parental education, } \\
\text { perceived physical activity } \\
\text { frequency and TV/video } \\
\text { watching. Analyses were } \\
\text { stratified by skin colour } \\
\text { (blacks and whites) }\end{array}$ & $\begin{array}{l}\text { Mean BF\% did not differ } \\
\text { according to the patterns } \\
\text { that contained mostly ultra- } \\
\text { processed foods }\end{array}$ \\
\hline $\begin{array}{l}\text { Wosje et al. }(2010)^{(29)} \text {; } \\
\text { USA }\end{array}$ & Longitudinal & $\begin{array}{l}n 292 \text { (age ranges: } \\
3 \cdot 8-4 \cdot 8,>4 \cdot 8-5 \cdot 8, \\
>5 \cdot 8-6 \cdot 8 \text { and }>6 \cdot 8- \\
7 \cdot 8 \text { years; follow-up } \\
\text { every } 4 \text { months) }\end{array}$ & $\begin{array}{l}\text { Food record; dietary } \\
\text { patterns }\end{array}$ & $\begin{array}{l}\text { BF in } \mathrm{kg} \text { evaluated by } \\
\text { DXA }\end{array}$ & $\begin{array}{l}\text { Race, sex, height, exact age, } \\
\text { energy intake, Ca intake, } \\
\text { accelerometer counts per } \\
\text { minute, TV viewing time, } \\
\text { outdoor playtime, other } \\
\text { dietary pattern score }\end{array}$ & $\begin{array}{l}\text { 'Dietary pattern } 1 \text { ', that } \\
\text { contained mostly ultra- } \\
\text { processed foods, was } \\
\text { positively related to BF } \\
\text { (consumption quartile } 4 \\
\text { presented higher fat mass } \\
\text { than quartiles } 1 \text { and } 2 \& 3 \text { ); } \\
\text { effect measure was not } \\
\text { presented }\end{array}$ \\
\hline $\begin{array}{l}\text { Alexy et al. }(2011)^{(30)} \\
\quad \text { Germany }\end{array}$ & Longitudinal & $\begin{array}{l}n 585 \text { ( } 3 \text { years old; } \\
\quad \text { followed up until } \\
18 \text { years old) }\end{array}$ & $\begin{array}{l}\text { Food record; } \\
\text { convenience foods } \\
\text { (CF) }\end{array}$ & $\begin{array}{l}\text { BF\% evaluated by } \\
\text { skinfolds (triceps } \\
\text { and subscapular) }\end{array}$ & $\begin{array}{l}\text { Age, residual energy, maternal } \\
\text { BMI, maternal education } \\
\text { level and physical activity }\end{array}$ & $\begin{array}{l}\text { No association among girls: } \\
\beta=0.012 ; P=0.6953 \\
\text { Among boys, CF consumption } \\
\text { at baseline significantly } \\
\text { predicted change in } \mathrm{BF} \% \text { : } \\
\beta=0.104 ; P=0.0098\end{array}$ \\
\hline $\begin{array}{l}\text { Feeley et al. }(2013)^{(31)} \text {; } \\
\text { South Africa }\end{array}$ & Longitudinal & $\begin{array}{l}n 1298 \text { (13 years old; } \\
4 \text { years of follow-up) }\end{array}$ & $\begin{array}{l}\text { FFQ about specific } \\
\text { foods; fast foods, } \\
\text { bakery products and } \\
\text { sweetened } \\
\text { beverages }\end{array}$ & $\begin{array}{l}\text { BF in } \mathrm{kg} \text { evaluated by } \\
\text { DXA }\end{array}$ & $\begin{array}{l}\text { Height and household durable } \\
\text { assets; stratified by sex }\end{array}$ & $\begin{array}{l}\text { Only sweetened beverages } \\
\text { consumption was positively } \\
\text { associated with BF in boys } \\
(\beta=0.018 ; P<0.05)\end{array}$ \\
\hline $\begin{array}{l}\text { Howe et al. }(2013)^{(32)} \\
\quad \text { New Zealand }\end{array}$ & Cross-sectional & $\begin{array}{l}n 681 \text { (mean age } 15.8 \\
\text { years old) }\end{array}$ & FFQ; dietary patterns & $\begin{array}{l}\text { BF in kg evaluated by } \\
\text { BIA (FMI was also } \\
\text { presented) }\end{array}$ & $\begin{array}{l}\text { Age, school decile and } \\
\text { ethnicity; stratified by sex }\end{array}$ & $\begin{array}{l}\text { 'Treat foods' pattern was not } \\
\text { associated with BF in the } \\
\text { adjusted model: } \beta=-3.57 \\
(95 \% \mathrm{Cl}-7.69,0.74)\end{array}$ \\
\hline
\end{tabular}


Table 2 Continued

\begin{tabular}{|c|c|c|c|c|c|c|}
\hline $\begin{array}{l}\text { Authors, year, } \\
\text { reference; country }\end{array}$ & Design & $\begin{array}{l}\text { Study population } \\
\text { ( } n \text {, age, follow-up) }\end{array}$ & Exposure & Outcome & Adjustment variables & Main results \\
\hline $\begin{array}{l}\text { Montoye et al. } \\
\quad(2013)^{(33)} ; \text { USA }\end{array}$ & $\begin{array}{l}\text { Intervention with } \\
\text { cross-sectional } \\
\text { analysis of the } \\
\text { baseline }\end{array}$ & $\begin{array}{l}n 214 \text { (mean age } 9 \cdot 8 \\
\text { years old) }\end{array}$ & $\begin{array}{l}\text { Specific question: junk } \\
\text { food consumption } \\
\text { (times/d): sweetened } \\
\text { beverages, French } \\
\text { fries and chips, } \\
\text { frozen/baked } \\
\text { desserts, sweets } \\
\text { made of chocolate }\end{array}$ & BF\% evaluated by BIA & $\begin{array}{l}\text { Age, gender, ethnicity and self- } \\
\text { reported physical activity }\end{array}$ & $\begin{array}{l}\text { No association between junk } \\
\text { food consumption and BF\% } \\
(\beta=-0.106 ; P=0.444)\end{array}$ \\
\hline $\begin{array}{l}\text { Yildirim et al. }(2013)^{(34)} \\
\quad \text { Netherlands }\end{array}$ & Intervention & $\begin{array}{l}n 1108 \text { (mean age } 12 \cdot 7 \\
\text { years old) }\end{array}$ & $\begin{array}{l}\text { Specific questions: } \\
\text { consumption of } \\
\text { sweetened } \\
\text { beverages (litres/d) } \\
\text { and sweetened and } \\
\text { salted snacks } \\
\text { (number of snacks/ } \\
\text { d) }\end{array}$ & $\begin{array}{l}\text { Skinfolds sum (in } \mathrm{mm} \text { ): } \\
\text { triceps, biceps, } \\
\text { suprailiac and } \\
\text { subscapular }\end{array}$ & Gender and ethnicity & $\begin{array}{l}\text { Consumption of sweetened } \\
\text { beverages }(\beta=0.02 ; 95 \% \mathrm{Cl} \\
-0.62,0.77) \text { and sweet } \\
(\beta=-0.19 ; 95 \% \mathrm{Cl}-0.53 \\
0.19) \text { and salted } \\
(\beta=-0.250 ; 95 \% \mathrm{Cl}-1.42, \\
0.36) \text { snacks was not } \\
\text { associated with the skinfolds } \\
\text { sum }\end{array}$ \\
\hline $\begin{array}{l}\text { Diethelm et al. } \\
\quad(2014)^{(35)} \text {; Germany }\end{array}$ & Longitudinal & $\begin{array}{l}n 371 \text { (6-7 years old; } \\
4 \text { years of follow-up) }\end{array}$ & $\begin{array}{l}\text { Food record; dietary } \\
\text { patterns }\end{array}$ & $\begin{array}{l}\text { BF in kg evaluated by } \\
\text { triceps, biceps, } \\
\text { suprailiac and } \\
\text { subscapular } \\
\text { skinfolds (FMI was } \\
\text { also presented) }\end{array}$ & $\begin{array}{l}\text { Baseline body composition, } \\
\text { sex, maternal overweight, } \\
\text { paternal education, } \\
\text { gestational age, birth weight } \\
\text { and breast-feeding }\end{array}$ & $\begin{array}{l}\text { Changing pattern by reduced } \\
\text { rank regression (savoury } \\
\text { foods) was associated with } \\
\text { change in FMl; comparing } \\
\text { subjects from the lowest } \\
\text { consumption tertile, those in } \\
\text { the highest tertile had } 74 \% \\
\text { more increase in FMI }\end{array}$ \\
\hline $\begin{array}{l}\text { Shang et al. }(2013)^{(36)} \\
\text { Canada }\end{array}$ & $\begin{array}{l}\text { Longitudinal, with } \\
\text { cross-sectional } \\
\text { analysis }\end{array}$ & $n 613$ (8-10 years old) & $\begin{array}{l}24 \mathrm{~h} \text { recall; dietary } \\
\text { patterns }\end{array}$ & BF\% evaluated by DXA & $\begin{array}{l}\text { Age, sex, daily energy intake, } \\
\text { daily average steps (steps/ } \\
\text { d), screen time (h/d), sleep } \\
\text { time }(\mathrm{h} / \mathrm{d}), \mathrm{mothher} \text { 's obesity } \\
\left(\mathrm{BMI} \geq 30 \mathrm{~kg} / \mathrm{m}^{2}\right) \text { and family } \\
\text { income }\end{array}$ & $\begin{array}{l}\text { Children with fast food pattern } \\
\text { score higher than P75 } \\
\text { presented higher BF\% than } \\
\text { those with score }<\text { P25 (41.8 } \\
v .40 .1 \% ; P<0.05) \text {. The fast } \\
\text { food pattern was positively } \\
\text { associated with BF\% } \\
(\beta=0.08 ; P=0.04)\end{array}$ \\
\hline $\begin{array}{l}\text { Leary et al. }(2015)^{(37)} \text {; } \\
\text { England }\end{array}$ & Longitudinal & $\begin{array}{l}n 4750 \text { (38 months; } \\
\text { followed up until } \\
15 \text { years old) }\end{array}$ & FFQ; dietary patterns & $\begin{array}{l}\text { BF in } k g \text { evaluated by } \\
\text { DXA }\end{array}$ & $\begin{array}{l}\text { Gender and age at the time of } \\
\text { body composition } \\
\text { measurement, energy intake } \\
\text { at } 38 \text { months for the four } \\
\text { dietary patterns, parental } \\
\text { factors (maternal and } \\
\text { paternal height, maternal } \\
\text { and paternal BMl, maternal } \\
\text { age, parity), social factors } \\
\text { (social class, maternal } \\
\text { education), birth weight, } \\
\text { gestational age, pubertal } \\
\text { status; stratified by sex }\end{array}$ & $\begin{array}{l}\text { The junk food dietary pattern } \\
\text { was associated with BF } \\
\text { (greater score at } 3 \text { years of } \\
\text { age was associated with an } \\
\text { increase in } \mathrm{BF} \text { at age } 15 \\
\text { years): } \beta=0.06 ; P=0.002 \text {; } \\
\text { fussy or snack: } \beta=-0.01 \text {; } \\
P=0.8\end{array}$ \\
\hline
\end{tabular}

$\mathrm{BF} \%$, body fat percentage; BIA, bioelectrical impedance analysis; BF, body fat; DXA, dual-energy X-ray absorptiometry; FMI, fat mass index; TV, television; P75, 75th percentile; P25, 25th percentile. 
Table 3 Summary of the selected studies that investigated the association between soft drink/sweetened beverages consumption and body fat in children and adolescents

\begin{tabular}{|c|c|c|c|c|c|c|}
\hline $\begin{array}{l}\text { Authors, year, } \\
\text { reference; } \\
\text { country }\end{array}$ & Design & $\begin{array}{l}\text { Study population } \\
\text { (n, age, follow-up) }\end{array}$ & Exposure & Outcome & Adjustment variables & Main results \\
\hline $\begin{array}{l}\text { Johnson et al. } \\
\quad(2007)^{(15)} \\
\text { England }\end{array}$ & Longitudinal & $\begin{array}{l}n 521 \text { (at } 5 \text { years } \\
\text { old) and } n 682 \\
\text { (at } 7 \text { years old); } \\
\text { followed up until } \\
9 \text { years old }\end{array}$ & $\begin{array}{l}\text { Food record; sweetened beverages } \\
\text { consumption evaluated by daily portion } \\
(1 \text { portion }=180 \mathrm{ml})\end{array}$ & $\begin{array}{l}\mathrm{BF} \text { in } \mathrm{kg} \text { evaluated } \\
\text { by DXA (FMI was } \\
\text { also presented) }\end{array}$ & $\begin{array}{l}\text { Sex, height at } 9 \text { years, child's BMI at baseline, TV } \\
\text { watching, maternal education, paternal class, } \\
\text { maternal and paternal BMI, misreporting of energy } \\
\text { intake (energy intake per EER), dietary energy } \\
\text { density, percentage of energy intake from fat and fibre } \\
\text { density }\end{array}$ & $\begin{array}{l}\text { No association between sweetened beverages } \\
\text { consumption and fat mass }(\Delta=-0.15, P=0.45 \\
\text { at } 5 \text { years; } \Delta=-0.11, P=0.41 \text { at } 7 \text { years })\end{array}$ \\
\hline $\begin{array}{l}\text { Denova- } \\
\text { Gutiérrez } \\
\text { et al. } \\
(2009)^{(16)} \text {; } \\
\text { Mexico }\end{array}$ & $\begin{array}{l}\text { Longitudinal } \\
\text { with cross- } \\
\text { sectional } \\
\text { analysis }\end{array}$ & $\begin{array}{l}n 1055(10-19 \\
\text { years old; mean } \\
\text { age } 14.5 \text { years })\end{array}$ & $\begin{array}{l}\text { FFQ; sweetened beverages consumption } \\
\text { evaluated by daily portion } \\
(1 \text { portion }=240 \mathrm{ml})\end{array}$ & $\begin{array}{l}\text { BF\% evaluated by } \\
\text { DXA (cut-off } \\
\text { points for excess } \\
\text { BF by age and } \\
\text { sex) }\end{array}$ & $\begin{array}{l}\text { Age, sex, sexual maturation, place of residence, } \\
\text { physical activity, father's education, total energy } \\
\text { intake, alcohol consumption and energy derived from } \\
\text { total fat intake }\end{array}$ & $\begin{array}{l}\text { To additional daily intake of sweetened beverages there } \\
\text { was an increase of } 0.8 \text { in } \mathrm{BF} \%(P<0.001) \text { and OR for } \\
\text { overweight was } 1.18(P<0.001) \text {; OR for }>3 \text { portions } \\
\text { was 2.06 }(P=0.004)\end{array}$ \\
\hline $\begin{array}{l}\text { Duncan et al. } \\
\quad(2008)^{(17)} ; \\
\text { New } \\
\text { Zealand }\end{array}$ & Cross-sectional & $\begin{array}{c}n 1229(5-11 \\
\text { years old })\end{array}$ & $\begin{array}{l}\text { FFQ; fast foods and soft drinks/sweetened } \\
\text { beverages consumption }\end{array}$ & $\begin{array}{l}\text { BF\% evaluated by } \\
\text { BIA (cut-off points } \\
\text { for excess BF: } \\
25 \% \text { for boys and } \\
30 \% \text { for girls) }\end{array}$ & $\begin{array}{l}\text { Sex, age, ethnicity, socio-economic status, physical } \\
\text { activity, active transport, sports participation, } \\
\text { breakfast, bought lunch, fast foods, sugary drinks, } \\
\text { weekday sleep and weekend sleep }\end{array}$ & $\begin{array}{l}\text { OR to have high } \mathrm{BF} \text { in those who consumed } 5+\text { fast food } \\
\text { portions/week was } 2.38(P \geq 0.05) \text {; in those who } \\
\text { consumed } 5+\text { portions sweetened beverages/week, } \\
2.37(P<0.05) \text {, compared with } 0 \text { portions (OR }=2.26 \text {; } \\
P<0.05 \text { for } 3-4 \text { portions/week) }\end{array}$ \\
\hline $\begin{array}{l}\text { Libuda et al. } \\
\quad(2008)^{(18)} \\
\quad \text { Germany }\end{array}$ & Longitudinal & $\begin{array}{l}n 244 \text { (9-13 years } \\
\text { old; } 5 \text { years of } \\
\text { follow-up) }\end{array}$ & $\begin{array}{l}\text { Food record; sweetened beverages } \\
\text { consumption evaluated by daily volume } \\
\text { (ml) }\end{array}$ & $\begin{array}{l}\text { BF\% evaluated by } \\
\text { skinfolds (triceps } \\
\text { and subscapular) }\end{array}$ & $\begin{array}{l}\text { Time in years after maximal growth velocity (equals } \\
\text { years of adolescence) as an indicator for pubertal } \\
\text { status, weight at birth, year of birth, maternal BMI and } \\
\text { educational level, energy derived from other sources } \\
\text { (residual energy) at the first assessment (total energy } \\
\text { intake minus energy from each of the beverage } \\
\text { groups), its interaction with time and the annual } \\
\text { change in residual energy }\end{array}$ & $\begin{array}{l}\text { No association between sweetened beverages } \\
\text { consumption and BF }\end{array}$ \\
\hline $\begin{array}{l}\text { Fiorito et al. } \\
\quad(2009)^{(19)} \\
\text { USA }\end{array}$ & Longitudinal & $\begin{array}{l}n 166 \text { (only girls; } \\
5 \text { years old; } \\
10 \text { years of } \\
\text { follow-up) }\end{array}$ & $\begin{array}{l}24 \mathrm{~h} \text { recall; sweetened beverages } \\
\text { consumption evaluated by daily portion } \\
(1 \text { portion }=240 \mathrm{ml})\end{array}$ & $\begin{array}{l}\text { BF\% evaluated by } \\
\text { DXA and } \\
\text { skinfolds (triceps } \\
\text { and subscapular) }\end{array}$ & $\begin{array}{l}\text { Sweetened beverage consumption at the age adiposity } \\
\text { was measured, energy intake at age } 5 \text { years, and } \\
\text { maternal BMI, parental education and family income } \\
\text { at study entry }\end{array}$ & $\begin{array}{l}\text { Sweetened beverages consumption at } 5 \text { years was a } \\
\text { predictor of adiposity at } 5,7,9,11,13 \text { and } 15 \text { years } \\
\text { Girls who consumed } \geq 2 \text { portions of sweetened } \\
\text { beverage at } 5 \text { years had higher BF\% values at } 5 \text { and } \\
15 \text { years compared with girls with lower sweetened } \\
\text { beverages consumption }\end{array}$ \\
\hline $\begin{array}{l}\text { Gomez- } \\
\text { Martinez } \\
\text { et al. } \\
(2009)^{(20)} \\
\text { Spain }\end{array}$ & Cross-sectional & $\begin{array}{c}n 1523 \text { (mean age } \\
15.4 \text { years old) }\end{array}$ & $\begin{array}{l}24 \mathrm{~h} \text { recall; sweetened beverages evaluated } \\
\text { by daily portion ( } 1 \text { average } \\
\text { portion }=336 \mathrm{ml} \text { ) }\end{array}$ & $\begin{array}{l}\text { BF\% evaluated by } \\
\text { skinfolds (triceps } \\
\text { and subscapular) }\end{array}$ & Only crude analysis. Stratified by age and sex & $\begin{array}{l}\text { No association between sweetened beverages } \\
\text { consumption and } \mathrm{BF}\end{array}$ \\
\hline $\begin{array}{l}\text { Bauer et al. } \\
\quad(2011)^{(21)} \\
\text { USA }\end{array}$ & $\begin{array}{l}\text { Intervention } \\
\text { with cross- } \\
\text { sectional } \\
\text { analysis }\end{array}$ & $\begin{array}{l}n 253 \text { (only girls; } \\
\text { mean age } \\
15.7 \text { years old) }\end{array}$ & $\begin{array}{l}\text { Specific question about parents' soft drink } \\
\text { consumption (portions/week) and } \\
\text { daughters' soft drink consumption (weekly } \\
\text { frequency in the last month) }\end{array}$ & $\begin{array}{l}\text { BF\% evaluated by } \\
\text { DXA }\end{array}$ & Age, race/ethnicity and parental education & $\begin{array}{l}\text { No association between soft drinks consumption and BF } \\
\% \text { (data not shown in tables) } \\
\text { No association between parents' soft drinks } \\
\text { consumption and daughters' BF\% }\end{array}$ \\
\hline $\begin{array}{l}\text { Laska et al. } \\
\quad(2012)^{(22)} \\
\text { USA }\end{array}$ & Longitudinal & $\begin{array}{l}n 562 \text { (mean age } \\
14 \cdot 6 \text { years old; } \\
2 \text { years of } \\
\text { follow-up) }\end{array}$ & $\begin{array}{l}24 \mathrm{~h} \text { recall; sweetened beverages } \\
\text { consumption evaluated by daily portion }\end{array}$ & $\begin{array}{l}\text { BF\% evaluated by } \\
\text { BIA }\end{array}$ & $\begin{array}{l}\text { Race, grade, parent education, school lunch, puberty, } \\
\text { total physical activity measured at baseline, study } \\
\text { (ECHO or IDEA) and total energy intake measured at } \\
\text { baseline }\end{array}$ & $\begin{array}{l}\text { Cross-sectional analysis: among girls, there was a } \\
\text { positive association between diet soft drinks } \\
\text { consumption and BF\% }(\beta=3.64 ; P<0.001) \\
\text { Longitudinal analysis: among boys, there was a positive } \\
\text { association between sweetened beverages } \\
\text { consumption and BF\% }(\beta=0.73 ; P=0.001)\end{array}$ \\
\hline
\end{tabular}




\begin{tabular}{|c|c|c|c|c|c|c|}
\hline $\begin{array}{l}\text { Authors, year, } \\
\text { reference; } \\
\text { country }\end{array}$ & Design & $\begin{array}{l}\text { Study population } \\
\text { (n, age, follow-up) }\end{array}$ & Exposure & Outcome & Adjustment variables & Main results \\
\hline $\begin{array}{l}\text { Sluyter et al. } \\
(2013)^{(23)} \\
\text { New } \\
\text { Zealand, } \\
\text { Australia, } \\
\text { Fiji and } \\
\text { Tonga }\end{array}$ & $\begin{array}{l}\text { Intervention } \\
\text { with cross- } \\
\text { sectional } \\
\text { analysis }\end{array}$ & $\begin{array}{c}n 5714(12-22 \\
\text { years old) }\end{array}$ & $\begin{array}{l}\text { Specific question: soft drink consumption } \\
\text { (last } 5 \text { d); portion = number of } \\
\text { glasses/cans (last day) }\end{array}$ & $\begin{array}{l}\text { BF\% evaluated by } \\
\text { BIA (BF in kg was } \\
\text { also presented) }\end{array}$ & Age, sex and ethnicity & $\begin{array}{l}\text { Among the combined ethnic groups, sweetened } \\
\text { beverages consumption presented a positive dose- } \\
\text { dependent association with BF\% and total BF; } \\
\text { consistent direction of the effects through the ethnic } \\
\text { groups: } 7 \text { of } 8 \text { positive associations }\end{array}$ \\
\hline $\begin{array}{l}\text { Zheng et al. } \\
\quad(2015)^{(26)} \\
\quad \text { Australia }\end{array}$ & Intervention & $\begin{array}{l}n 158 \text { ( } 8 \text { years old; } \\
3.5 \text { years of } \\
\text { follow-up) }\end{array}$ & $\begin{array}{l}24 \mathrm{~h} \text { recall; sweetened beverages } \\
\text { consumption evaluated by daily portion } \\
(1 \text { portion }=100 \mathrm{ml})\end{array}$ & $\begin{array}{l}\text { BF\% evaluated by } \\
\text { BIA }\end{array}$ & $\begin{array}{l}\text { Baseline age, gender, BMI Z-score, SEIFA score, } \\
\text { maternal age at birth, parental education level, } \\
\text { parental countries of birth, maternal age at birth, } \\
\text { presence of gestational diabetes, breast-feeding } \\
\text { characteristics, pubertal status, randomization group } \\
\text { and total energy intake }\end{array}$ & $\begin{array}{l}\text { For each increase of } 100 \mathrm{ml} \text { in the daily intake of } \\
\text { sweetened beverages at } 9 \text { years, there was an } \\
\text { increase of } 0.9 \text { percentage points in } \mathrm{BF}(P=0.004) \\
\text { Trend of dose-response was found for quartiles of } \\
\text { sweetened beverages consumption and BF\% } \\
(P \text { trend }=0.005)\end{array}$ \\
\hline
\end{tabular}

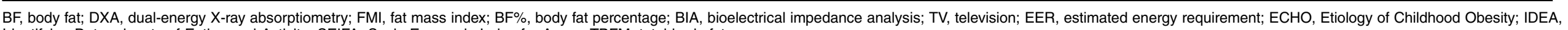
Identifying Determinants of Eating and Activity; SEIFA, Socio-Economic Index for Areas; TBFM, total body fat mass. 
Among the studies that evaluated other specific ultraprocessed foods, two of them found associations in a negative direction, such that they showed that higher consumption of chocolate and ready-to-eat cereals was related to a lower percentage of body fat. These findings may reflect residual confounding. Michels et al. ${ }^{(40)}$ did not adjust for consumption of milk (that was added to ready-to-eat cereals) or for physical activity, although these variables might have a correlation with body fat. Cuenca-García et al. ${ }^{(39)}$ evaluated chocolate consumption from a $24 \mathrm{~h}$ recall, an instrument that does not measure dietary habits. Additionally, because of the cross-sectional design of the study by Cuenca-García et $a{ }^{(39)}$, it is possible that individuals with lower percentages of body fat had higher consumption of chocolate only over the $24 \mathrm{~h}$ preceding the interview.

It is important to emphasize that only one of the studies selected for the present review reported the parameters that were used for sample size calculation ${ }^{(38)}$ and none presented a statistical power calculation. Nevertheless, the scores relating to study quality, as evaluated through the STROBE and CONSORT Statements, were considered good. There was no difference in the mean scores for quality between studies that did or did not find an association (data not shown).

Although ultra-processed foods are a major source of energy intake, they are just one group of foods among all the possible sources of energy intake in the diet. Therefore, to assess the effect of the energy provided by ultra-processed foods on body fat levels, it is important to disentangle the effect of ultra-processed foods from the effect of other sources of energy. Consequently, studies that adjusted for total energy intake (including energy provided by ultra-processed foods) may in fact have overadjusted for the exposure, thus decreasing the magnitude of the association between consumption of ultraprocessed foods and body fat. For this reason, we take the view that the adjustment should be limited to residual energy solely from other sources. Nevertheless, seven of the nine studies examined here that adjusted for total energy intake found positive associations ${ }^{(16,19,22,26,29,36,37)}$.

Regarding the strategies used by the authors of the studies selected for the current analysis to decrease the occurrence of bias, self-reporting errors were considered in five studies ${ }^{(15,16,18,24,26)}$. One study evaluated underreporting and over-reporting of energy intake (daily intakes $<79 \%$ and $>121 \%$ of the estimated energy requirement, respectively). However, they did not exclude these cases from the analysis, under the argument that in doing so, the children who were of greatest interest for the study (those with highest percentages of body fat) would probably be excluded ${ }^{(15)}$. Therefore, the implausible reports were used as a covariate in the adjusted analysis. Individuals with implausible energy intake (under-reported or over-reported) were excluded in two studies ${ }^{(27,33)}$. Cuenca-García et al. ${ }^{(39)}$ performed additional analyses in 
which obese adolescents were excluded, to prevent underestimated reporting of chocolate intake. However, after these analyses, the results did not change. Some of the studies reported using standardized protocols for anthropometric measurements ${ }^{(16,23,25,28,32,34-36)}$, to decrease occurrences of measurement errors.

Among the limitations of the present review, the great variability of methods used to investigate food consumption can be highlighted, along with the great variability of the instruments used to assess body composition. These factors hindered evaluation of the data by means of meta-analysis. The articles included in the review looked only at specific products and did not apply the NOVA classification. In fact, so far, only two studies have applied the NOVA classification to assess associations: not with body fat but with obesity and weight gain. Louzada et $a l^{(10)}$ were the first to use this indicator in a cross-sectional study to evaluate the association with obesity. Mendonça et al. ${ }^{(11)}$ applied this indicator in the first cohort study that was planned to evaluate the effect of ultra-processed food consumption on weight gain.

On the other hand, to the best of our knowledge, the present systematic review is the first addressing the association between consumption of ultra-processed foods and body fat levels among children and adolescents. Investigations on consumption of ultra-processed foods during childhood have gained importance because the dietary habits acquired over this period tend to be kept throughout life, which can influence the prevalence of obesity in this population ${ }^{(42,43)}$.

\section{Conclusion}

It is evident that the great majority of the literature on the association between consumption of ultra-processed foods and body fat levels presents positive directions (i.e. increased consumption ends up increasing body fat levels). Most of the studies with designs of greater robustness, and which used DXA to evaluate body composition, showed positive associations between consumption of ultra-processed foods and body fat levels.

Despite the large number of studies on the association between dietary habits and body fat levels that are available in the literature, there is a lack of studies exploring the association between consumption of ultra-processed foods and obesity among children and adolescents. Use of a standardized food classification, such as NOVA, which makes it possible to consider the level of food processing, is much needed to uncover the role of such foods in obesity epidemics and to enable comparability between the findings of upcoming studies.

\section{Acknowledgements}

Acknowledgements: The authors thank the National Support Program for Centers of Excellence (PRONEX-CAPES) and Brazilian National Research Council (CNPq). Financial support: This research received no specific grant from any funding agency in the public, commercial or not-forprofit sectors. Conflict of interest: None. Authorship: All authors contributed substantially to the conception and design, data acquisition, analysis and/or interpretation. C.S.C. drafted the article and B.D.-P., M.C.F.A. and I.S.S. reviewed it critically for important intellectual content. All authors approved the final version to be published. Ethics of buman subject participation: Not applicable.

\section{Supplementary material}

To view supplementary material for this article, please visit https://doi.org/10.1017/S1368980017001331

\section{References}

1. Ng M, Fleming T, Robinson M et al. (2014) Global, regional, and national prevalence of overweight and obesity in children and adults during 1980-2013: a systematic analysis for the Global Burden of Disease Study 2013. Lancet 384, 766-781.

2. Popkin BM (2006) Technology, transport, globalization and the nutrition transition food policy. Food Policy 31, 554-569.

3. Popkin BM (2006) Global nutrition dynamics: the world is shifting rapidly toward a diet linked with noncommunicable diseases. Am J Clin Nutr 84, 289-298.

4. Owen N, Sparling PB, Healy GN et al. (2010) Sedentary behavior: emerging evidence for a new health risk. Mayo Clin Proc 85, 1138-1141.

5. Martins APB, Levy RB, Claro RM et al. (2013) Participação crescente de produtos ultraprocessados na dieta brasileira (1987-2009). Rev Saude Publica 47, 656-665.

6. Monteiro CA, Cannon G, Moubarac J-C et al. (2017) The UN Decade of Nutrition, the NOVA food classification and the trouble with ultra-processing. Public Health Nutr (Epublication ahead of print version).

7. Pan American Health Organization (2015) Ultra-Processed Food and Drink Products in Latin America: Trends, Impact on Obesity, Policy Implications. Washington DC: PAHO.

8. Food and Agriculture Organization of the United Nations (2015) Guidelines on the Collection of Information on Food Processing Through Food Consumption Surveys. Rome: FAO.

9. Monteiro CA, Levy RB, Claro RM et al. (2010) A new classification of foods based on the extent and purpose of their processing. Cad Saude Publica 26, 2039-2049.

10. Louzada MLdC, Baraldi LG, Steele EM et al. (2015) Consumption of ultra-processed foods and obesity in Brazilian adolescents and adults. Prev Med 81, 9-15.

11. Mendonça RdD, Pimenta AM, Gea A et al. (2016) Ultraprocessed food consumption and risk of overweight and obesity: the University of Navarra Follow-Up (SUN) cohort study. Am J Clin Nutr 104, 1433-1440.

12. Singh AS, Mulder C, Twisk JW et al. (2008) Tracking of childhood overweight into adulthood: a systematic review of the literature. Obes Rev 9, 474-488.

13. Vandenbroucke JP, Von Elm E, Altman DG et al. (2007) Strengthening the Reporting of Observational Studies in Epidemiology (STROBE): explanation and elaboration. Ann Intern Med 147, W163-W194.

14. Moher D, Hopewell S, Schulz KF et al. (2010) CONSORT 2010 explanation and elaboration: updated guidelines for 
reporting parallel group randomised trials. J Clin Epidemiol 63, e1-e37.

15. Johnson L, Mander AP, Jones LR et al. (2007) Is sugarsweetened beverage consumption associated with increased fatness in children? Nutrition 23, 557-563.

16. Denova-Gutiérrez E, Jiménez-Aguilar A, Halley-Castillo E et al. (2009) Association between sweetened beverage consumption and body mass index, proportion of body fat and body fat distribution in Mexican adolescents. Ann Nutr Metab 53, 245-251.

17. Duncan JS, Schofield G, Duncan EK et al. (2008) Risk factors for excess body fatness in New Zealand children. Asia Pac J Clin Nutr 17, 138-147.

18. Libuda L, Alexy U, Sichert-Hellert W et al. (2008) Pattern of beverage consumption and long-term association with body-weight status in German adolescents - results from the DONALD study. Br J Nutr 99, 1370-1379.

19. Fiorito LM, Marini M, Francis LA et al. (2009) Beverage intake of girls at age 5 y predicts adiposity and weight status in childhood and adolescence. Am J Clin Nutr 90, 935-942.

20. Gómez-Martínez S, Martín A, Romeo J et al. (2009) Is soft drink consumption associated with body composition? A cross-sectional study in Spanish adolescents. Nutr Hosp $\mathbf{2 4}$ 97-102.

21. Bauer KW, Neumark-Sztainer D, Fulkerson JA et al. (2011) Familial correlates of adolescent girls' physical activity, television use, dietary intake, weight, and body composition. Int J Behav Nutr Phys Act 8, 25.

22. Laska MN, Murray DM, Lytle LA et al. (2012) Longitudinal associations between key dietary behaviors and weight gain over time: transitions through the adolescent years. Obesity (Silver Spring) 20, 118-125.

23. Sluyter JD, Scragg RK, Plank LD et al. (2013) Sizing the association between lifestyle behaviours and fatness in a large, heterogeneous sample of youth of multiple ethnicities from 4 countries. Int J Behav Nutr Phys Act 10, 115.

24. Bigornia SJ, LaValley MP, Noel SE et al. (2015) Sugarsweetened beverage consumption and central and total adiposity in older children: a prospective study accounting for dietary reporting errors. Public Health Nutr 18, $1155-1163$.

25. Laverty AA, Magee L, Monteiro CA et al. (2015) Sugar and artificially sweetened beverage consumption and adiposity changes: national longitudinal study. Int J Behav Nutr Phys Act 12, 137.

26. Zheng M, Allman-Farinelli M, Heitmann B et al. (2015) Liquid versus solid energy intake in relation to body composition among Australian children. J Hum Nutr Diet 28, 70-79.

27. Phillips SM, Bandini LG, Naumova EN et al. (2004) Energy-dense snack food intake in adolescence: longitudinal relationship to weight and fatness. Obes Res $\mathbf{1 2}$ 461-472.
28. Ritchie LD, Spector P, Stevens MJ et al. (2007) Dietary patterns in adolescence are related to adiposity in young adulthood in black and white females. J Nutr 137, 399-406.

29. Wosje KS, Khoury PR, Claytor RP et al. (2010) Dietary patterns associated with fat and bone mass in young children. Am J Clin Nutr 92, 294-303.

30. Alexy U, Libuda L, Mersmann S et al. (2011) Convenience foods in children's diet and association with dietary quality and body weight status. Eur J Clin Nutr 65, 160-166.

31. Feeley AB, Musenge E, Pettifor JM et al. (2013) Investigation into longitudinal dietary behaviours and household socioeconomic indicators and their association with BMI $Z$-score and fat mass in South African adolescents: the Birth to Twenty (Bt20) cohort. Public Health Nutr 16, 693-703.

32. Howe AS, Black KE, Wong JE et al. (2013) Dieting status influences associations between dietary patterns and body composition in adolescents: a cross-sectional study. Nutr J 12, 51 .

33. Montoye AH, Pfeiffer KA, Alaimo K et al. (2013) Junk food consumption and screen time: association with childhood adiposity. Am J Health Behav 37, 395-403.

34. Yildirim M, Singh AS, Velde SJ et al. (2013) Mediators of longitudinal changes in measures of adiposity in teenagers using parallel process latent growth modeling. Obesity (Silver Spring) 21, 2387-2395.

35. Diethelm K, Günther AL, Schulze MB et al. (2014) Prospective relevance of dietary patterns at the beginning and during the course of primary school to the development of body composition. Br J Nutr 111, 1488-1498.

36. Shang L, O'Loughlin J, Tremblay A et al. (2013) The association between food patterns and adiposity among Canadian children at risk of overweight. Appl Physiol Nutr Metab 39, 195-201.

37. Leary S, Lawlor D, Smith GD et al. (2015) Behavioural early-life exposures and body composition at age 15 years. Nutr Diabetes 5, e150.

38. Chaves OC, Franceschini Sdo C, Ribeiro SMR et al. (2013) Anthropometric and biochemical parameters in adolescents and their relationship with eating habits and household food availability. Nutr Hosp 28, 1352-1356.

39. Cuenca-García M, Ruiz JR, Ortega FB et al. (2014) Association between chocolate consumption and fatness in European adolescents. Nutrition 30, 236-239.

40. Michels N, De Henauw S, Breidenassel C et al. (2015) European adolescent ready-to-eat-cereal (RTEC) consumers have a healthier dietary intake and body composition compared with non-RTEC consumers. Eur J Nutr 54, 653-664.

41. Hu FB (2002) Dietary pattern analysis: a new direction in nutritional epidemiology. Curr Opin Lipidol 13, 3-9.

42. Madruga SW, Araújo CLP, Bertoldi AD et al. (2012) Manutenção dos padrões alimentares da infância à adolescência. Rev Saude Publica 46, 376-386.

43. Ventura AK \& Worobey J (2013) Early influences on the development of food preferences. Curr Biol 23, R401-R408. 